\title{
Poezja stanu wojennego jako tekst kultury
}

Anna Skoczek 


\section{Anna Skoczek}

\section{Poezja stanu wojennego jako tekst kultury}

Tą oto pieśnią o wolność wołamy („Obóz polityczny w Chełmie założyli...”)

$\mathrm{K}^{\mathrm{o}}$ od kulturowy poezji stanu wojennego tworzą: tradycja romantyczna, nurt kolędowo-modlitewny, aluzje literackie, cytaty i pastisze oraz kontrafaktury.

Kontrafaktura jest zjawiskiem często spotykanym na gruncie kultury werbalno-melicznej. Znana od czasów starożytnych, była popularna także w okresie reformacji, kiedy to odnotowano praktykę zamiany tekstu świeckiego na religijny. Łacińskie contrafactum pochodzi od contrafacere, co znaczy 'podrabiać'. Jerzy Ziomek podaje następującą definicję tego terminu:

Jest to użycie istniejącej już melodii do nowo ułożonego tekstu, melodii zazwyczaj o przeznaczeniu wokalnym, wykonywanej na tyle często z tekstem starym, że między muzyką a słowem zawiązał się stosunek trwałej przynależności, dostatecznie silnej, by zastąpienie jednego tekstu słownego drugim było odczuwane jako naruszenie pewnej wspólnoty strukturalnej ${ }^{1}$.

W okresie stanu wojennego powstało wiele przeróbek i nowych wersji tekstów, nawiązujących do aktualnej sytuacji. Zbiorowy śpiew był wyrazem buntu i manifestacją, że mimo okowów nie złamano ducha narodu. Poczucie wspólnoty zbiorowego losu układało ton pieśni internowanych w jeden akord: „tą pieśnią o wolność wołamy”.

Pieśń, piosneczka w polskiej narodowej kulturze ma długa tradycję. W okresie zaborów i powstań zaświadczała o patriotyzmie. Jej rolę tak określił Stanisław Tarnowski:

\footnotetext{
${ }^{1}$ J. Ziomek, Kontrafaktura, w: idem, Prace ostatnie, Warszawa 1994, s. 265.
} 
Nigdy ona tak nie kwitła, nigdy nie powstała tak licznie i często, nigdy nie była też tak lubianą, tak skwapliwie chwytaną, śpiewaną i słuchaną z takim upodobaniem jak w latach między 1831 a 1846. Biedna piosneczka, najmniejszy z małych rodzajów poezji, ona przecież spełniała niemały obowiązek patriotyczny i niemały użytek miłosierny. Miała słowo na każde z najbliższych uczuć, na to, co było przedmiotem wszystkich myśli i rozmów, a nieraz ona jedna była tym słowem. Broszur, dzienników nie było, z emigracji książki, poważna poezja dostawały się rzadko i z trudnością, cóż było robić, chwytano się piosneczki, ona zastępowała broszury, artykuły polityczne lub historyczne o ostatnich wypadkach, nieraz i wspólną lekturę ${ }^{2}$.

Z kolei Maria Janion fenomen pieśni w kulturze omawianego przez nas okresu tak charakteryzuje:

Popularność pieśni w kulturze politycznej czasów strajku wyrasta z tych samych korzeni, co analogiczne zjawiska okresu międzypowstaniowego, ale jest czymś treściowo i funkcjonalnie odmiennym. Łączy cechy popularnego obiegu literatury „wysokiej” oraz spontanicznej twórczości regulowanej zarówno wzorami tradycji, jak normami kultury środowiska ludowego. W twórczości tej dokonuje się swoisty proces ujednolicenia różnych inspiracji na poziomie umożliwiającym powszechną zrozumiałość, emocjonalną bliskość i praktyczną użyteczność tekstu³

W okresie stanu wojennego odżyła retoryka pieśni narodowych i żołnierskich okresu pierwszej i drugiej wojny światowej, religijnych, ludowych, ale takze popularnych w latach siedemdziesiątych polskich przebojów muzyki pop. Znana melodia służyła jako wzorzec meliczny, utrwalony w pamięci historyczny tekst stawał się źródłem inspiracji. Najczęściej w kontrafakturach wykorzystywano incipit. Poecie, bywało że mało wprawnemu, czasami autorowi ,jednego wiersza", w ten sposób łatwiej było skonstruować swoją wypowiedź liryczną. Realia grudnia 1981 roku zostały wpisane w kontekst historyczny walk o wolność, podejmowanych przez Polaków od czasu zaborów. Doświadczenia lat osiemdziesiątych zapewniły ciągłość tradycji „między dawnymi a młodszymi laty".

Jednym z ciekawszych zjawisk kultury Sierpnia '80 i Grudnia '81 było włączenie fragmentu dramatu mistycznego Juliusza Słowackiego Ksiq̨dz Marek, znanego jako Pieśn konfederatów barskich ${ }^{4}$, do kanonu tekstów strajkowych. W okresie stanu wojennego powstała kontrafaktura tej pieśni Modlitwa Strzebieliniska:

O Boże wielki, Panie nasz jedyny,

Zmieć niewolnictwo z serca Europy,

\footnotetext{
${ }^{2}$ M. Janion, Stow i symbol w miesiqcach przelomu, w: Almanach stanu wojennego, nr 1: Kongres Kultury Polskiej, Warszawa 1982, s. 20-21.

${ }^{3}$ Ibidem, s. 22.

${ }^{4}$ Zob. J. Stowacki, Ksiqdz Marek, opr. M. Piwińska, Wrocław-Warszawa-Kraków 1991 (BN I 29), s. 46 (Pieśí konfederatóu' za scenq).
} 
Polska Cię woła, narodów sumienie,

W Tobie zbawienie.

Matko Maryjo, do Ciebie wołamy,

My z cel więziennych, duchem niepodlegli,

Królowo Polski, bądź nam tarczą męstwa,

Wiedź do zwycięstwa.

W kontrafakturze został wykorzystany ten sam wzorzec metryczny (strofa saficka 11/5-zgloskowa).

Utwór Słowackiego jest pieśnią o wierności Bogu, który jest dla narodu źródłem siły i nadziei. Modlitwa Strzebieliniska wychodzi poza ten kontekst. Na plan pierwszy wysuwają się akcenty patriotyczne:

Precz z Targowicą i jarzmem Moskali

oraz głosy domagające się suwerenności:

Nic o nas bez nas, taka nasza wola.

Powtórzone zostały hasła demokratów dziewiętnastowiecznych: „Za wolność naszą i waszą”;

Wolni z wolnymi w duchowej jedności,

Równi z równymi bratać się pragniemy

— a w apostrofach do Boga poeta domaga się sprawiedliwości na świecie.

Melodia do Pieśni konfederatów barskich powstała w latach siedemdziesiątych i pochodzi z inscenizacji dramatu Słowackiego na jednej ze scen warszawskich. W przypadku tej kontrafaktury powinowactwo przez melodię jest przykładem zapożyczenia nawiązującego 5 .

W okresie stanu wojennego nieoczekiwaną popularność zdobyła także pieśń Feliksa (inc. „Nie dbam, jaka spadnie kara...”) z III części Dziadów (akt I, sc. 1) Adama Mickiewicza. Pieśń tę śpiewali powstańcy podczas zrywu w 1863 roku $^{6}$. Z czasem weszła do śpiewników patriotycznych i robotniczych wraz z zapisem nutowym. W latach osiemdziesiątych XX wieku powstała kontrafaktura, wykazująca związek z oryginałem przez wspólny motyw uwięzienia, przygotowania narzędzi zbrodni i samej zemsty. Inspirujący wpływ pierwowzoru jest tak silny, że można mówić nawet o pewnym stopniu identyfikacji kontrafaktury z wierszem Mickiewicza:

Nie dbam, jaka spadnie kara,

Areszt, obóz czy więzienie,

Zawsze będę zaszczycony,

Pracować mogąc dla WRONy.

5 Terminologia Jerzego Ziomka, op. cit., s. 276.

${ }^{6}$ Kartka z odręcznic przepisanym tckstcm utworu wraz z powstańczym cmblematem była przechowywana jako najdroższa pamiątka przez uczestnika walk styczniowych Antonicgo Medyckicgo — zob. D. B. Kacnclson, $Z$ dziejów polskiej pieśni powstańczej XIX wieku. Folklor poustania styczniourego, Wrocław 1974, s. 15. 
W Białołęce siedząc w celi,

Wyrwę z pryczy drut skręcony,

Może kiedyś z tego drutu

Zrobi się potrzask dla WRONy?

Kiedy wreszcie mnie wypuszcza,

Pójdę w pole chronić plony.

Będę służył rolnikowi

Jako żywy strach na WRONy.

Za to ześlą nas pod Olkusz,

Lecz nie będę tym zmartwiony.

Ołów cennym jest surowcem -

Zrobię z niego śrut na WRONy.

Jak oślepnę tam pod ziemią,

Mam już zawód wyuczony.

Wnet wyuczę się wyplatać

$\mathrm{Z}$ wikliny klatki na WRONy.

Zgwałcę żonę komendanta,

Gdy ją zdybię bez ochrony.

Może owoc tego związku

Zapoluje też na WRONy.

Motyw gwałtu i prokreacji w celu zemsty znany jest z legend historycznych i folkloru więziennego. Występuje także w „pieśni opryszków”, na przykład w wierszu Włodzimierza Zagórskiego pojawiają się słowa:

Jaśka tu na drzwiach powieszę,

A z Jaśkową się ucieszę,

A Jaśkowej łeb rozwalę

I na wiwat karczmę spalę

oraz kuplecie Jeremiego Przybory o „odrażającym drabie” z Kabaretu Starszych Panów, co świadczy o nawiązaniach do współczesnej kultury popularnej. Kontrafaktura ta, podobnie jak wcześniejsza czy jak fragmenty utworów Słowackiego i Mickiewicza, jest przykładem obecności tradycji romantycznych w świadomości Polaków lat osiemdziesiątych.

W kulturę stanu wojennego wpisały się także pieśni, którym historia nadała walor szczególny.

Mazurek Dąbrowskiego byl licznie parafrazowany ze względu na wartości i symbolikę tekstu w okresie powstań narodowych w latach 1830-1831 i 1863-1864 ${ }^{7}$. Śpiewano go także podczas strajku w Stoczni Gdańskiej w sierpniu 1980 roku oraz w trakcie akcji pacyfikacyjnych w grudniu

\footnotetext{
7 Zob. Z. Kloch, Poezja pierwszej wojny. Tradycja i konwencje, Wrocław-Warszawa-Kraków 1986, s. 107-109.
} 
1981 roku. Hymn państwowy stał się pieśnią robotników. Słowa Józefa Wybickiego, napisane w 1797 roku w Reggio dla Legionów Jana Henryka Dąbrowskiego, również dla Polaków w latach osiemdziesiątych oznaczały nadzieję i pokrzepienie. Przynosiły wezwanie do męstwa i zapowiadały zwycięstwo.

W strajkującej Stoczni śpiewano „Jeszcze Polska” nie tylko, żeby sobie dodać otuchy, ale żeby utwierdzić się w sensie swego działania, żeby dowiedzieć się, co robić dalej. Słowa "Jeszcze Polska nie zginęła, póki my żyjemy" zawierają w sobie wieczystą osobliwą prawdę. Każde pokolenie, które było, które jest i które będzie, może śpiewać „póki my żyjemy” — i każde ma rację. Zawsze. Póki mamy w sercach ojczyznę, póty Polska nie zginęła. Mickiewicz w wykładach w Collège de France z 1842 roku mówit, że słowa tej pieśni stwarzaja polską historię współczesną. Znaczą one - wyjaśniał, że „ludzie zachowujący w sobie to, co stanowi istotę narodowości polskiej, zdolni są przedłużý byt ojczyzny niezależnie od wszelkich warunków politycznych i mogą dążyć do jego przywrócenia. Albowiem człowiek — gdziekolwiek się znajduje, skoro myśli, czuje, działa, może być pewny, że w tejże samej chwili tysiące jego współrodaków myślą, czują i działają podobnie jak on. Ta spójnia niewidoma zawiazzuje narodowość”. (...) Dali do zrozumienia [polscy robotnicy - A. S.]: będziemy używać hymnu narodowego i godła narodowego, i barw narodowych wtedy, kiedy jest to nam niezbędnie potrzebne do $\dot{z} y c i{ }^{8}$.

W kontrafakturze polskiego hymnu:

Jeszcze Polska nie zginęła,

Póki tutaj trwamy,

Wolność dla nas wywalczymy

Krzyżem i strajkami

— szlak wolności przebiega „z Wybrzeża do Śląska”. Poeta powołał Panteon bohaterów, należą do niego Lech Wałęsa, Marian Jurczyk, Zbigniew Bujak — „Bonaparte” z pierwotnego tekstu:

\section{Wolność wywalczymy \\ Krzyżem i strajkami, \\ Bo nas Zbyszek uczył, \\ Jak zwyciężać mamy.}

Równie chętnie i często była wykorzystywana Rota Marii Konopnickiej, rozpowszechniona także przez wzorzec pieśni religijnej „Nie rzucim, Chryste świątyń, twych”. Po raz pierwszy Rota została zaśpiewana w pięćsetną rocznicę bitwy pod Grunwaldem w 1910 roku. Śpiewano ją także przy odsłonięciu pomnika grunwaldzkiego w Krakowie i na frontach pierwszej wojny. Pieśń tę znali między innymi zołnierze słynnej II Brygady 9 .

${ }^{8}$ M. Janion, op. cit.

9 Zob. relacja gen. Micczysława Boruty-Spiechowicza w: J. Czerwieński, W. Zatorski, Byleś Polsko wolną była. Zbiór 
Rotę-przysięgę:

Nie rzucim Cię, Wałęso nasz,

Nie damy pogrześć sprawy

lub

Nie będzie junta pluć nam w twarz

składał także polski robotnik w latach osiemdziesiątych XX wieku. Pieśń ta, pretendująca w historii Polski do roli hymnu narodowego, w okresie stanu wojennego stawała się hymnem robotników, o czym świadczy fragment Roty obozowej:

My robotnicy ziemi tej,

My grudzień pamiętamy,

Przelanej robotniczej krwi

Zapomnieć wam nie damy.

(ref::) Więc solidarnie walczmy znów,

Tak nam dopomóż Bóg;

Wszystkie kontrafaktury świadczą o niezłomnej woli narodu dążącego do uzyskania pełnej wolności, są wyrazem nadziei, że czas zniewolenia minie — „równy znów bratu będzie brat” i prawda zatriumfuje. Wykorzystywana symbolika „złotego rogu” sytuowała marzenia Polaków lat osiemdziesiątych w tej samej tradycji snów o wielkości i potędze ojczyzny, która była udziałem poprzednich pokoleń. Obecność w obozowym repertuarze pieśni powstańczych świadczy o tym, że współcześni robotnicy Warszawy, Śląska, Krakowa, Gdańska czuli się spadkobiercami idei wolnościowych dziewiętnastowiecznych patriotów polskich, ale także ideałów rewolucyjnych proletariatu $^{10}$. Nadawcy tekstów okolicznościowej poezji stanu wojennego wykazują świadomość dziewiętnastowiecznej demokracji, myśli PPS, ale i świadomość socjalistyczną PZPR. Nie ma $\mathrm{w}$ tych utworach radykalizmu, nawoływania do przeprowadzenia zasadniczych zmian w życiu politycznym, powszechne jest natomiast rozczarowanie i rozgoryczenie do systemu ustrojowego i aparatu władzy, który stoi na jego straży. W tej sytuacji naturalną rzeczą okazało się odrodzenie polskich pieśni rewolucyjnych.

Szlachta $w$ roku 1831 Gustawa Ehrenberga, Mazur kajdaniarski Ludwika Waryńskiego, Warszawianka Wacława Święcickiego stały się źródłem inspiracji. Podobnie jak w poprzednich kontrafakturach melodia pełni tu funkcje identyfikacyjne, staje się interpretantem ${ }^{11}$.

pieśni i piosenek polskich z melodiami, Kraków 1988, s. 99.

10 Zespół „Kabaryna” ('karcer', 'izolatka') w Głogowie odtwarzał Śpiew Rajnolda Suchodolskiego z roku 1830, zmieniając tylko jeden wers: „Solidarność, Tobie cześć!”, w innych obozach śpicwano Warszauiankę Casimira Delavigne (również z powstania listopadowego) oraz Pieśn strzelców Władysława Ludwika Anczyca, popularną w dobie powstania styczniowego, a także Ostatni mazur z tego samego okresu.

$"$ Terminologia proponowana przez Jerzego Ziomka, op. cit., s. 270. 
ZX Pawilonem Cytadeli Warszawskiej wiąże się powstanie dwóch pieśni: Mazura kajdaniarskiego w 1886 roku i Warszawianki w roku $1879^{12}$. Tak jak Ludwik Waryński chciał swoim utworem dodać otuchy uwięzionym przyjaciołom, członkom „Proletariatu”, tak anonimowy autor osadzony w obozie w Kamiennej Górze, gdzie w styczniu 1982 roku nowy Mazur kajdaniarski został napisany, współtowarzyszom niedoli głosi pieśń zwycięstwa:

\section{Solidarność za kratkami \\ Śpiewa dyktatorom, \\ Że victoria będzie z nami, \\ Choć nas w tiurmy biorą.}

Dwie pierwsze i dwie ostatnie strofy tej pieśni są nieznacznie zmienionym powtórzeniem tekstu Waryńskiego; kontrafaktura napisana w Iławie na okładce dzieł Lenina ${ }^{13}$ jest bardziej samodzielna, a oryginałowi bliska przez poczucie solidamości z „buntowniczą wiarą”.

W latach osiemdziesiątych można odnotować zjawisko hipertrofii pieśni legionowych. Przez długie lata przemilczane, nieobecne na oficjalnych uroczystościach i akademiach, pielęgnowane w zaciszu domowym, w okresie stanu wojennego zabrzmiały ze zdwojoną siła. Była w tym chęć demonstracji, ale także ważniejsza - świadomość dziedzictwa kulturowego, wskazanie na patriotyczną tradycję i manifestowanie własnych korzeni. Za kratami w Łupkowie, Głogowie, Kwidzyniu śpiewa się Pierwszq kadrowa; hymn pierwszego od czasów powstania styczniowego oddziału Wojska Polskiego, który w sierpniu 1914 roku wyruszył na front z krakowskich Oleandrów: My Pienvsza Brygada; piosenkę szwoleżerów Więc pijmy wino, szwoleżerowie; pieśń lwowskich Orląt Tylko mi Ciebie, Mamo; Biate róże; Wojenko, wojenko; Piechotę. Obok tekstów oryginalnych pojawiają się liczne trawestacje.

Najpopularniejsza okazała się pieśń ze słowami Tadeusza Biernackiego i Andrzeja Hałacińskiego, nazwana przez Józefa Piłsudskiego „najdumniejszą pieśnią, jaką kiedykolwiek Polska stworzyła” - My Pienusza Brygada ${ }^{14}$. Hymn internowanych $w$ Suwatkach wykorzystuje wzorzec metryczny i melodyczny pieśni legionistów. Duch pierwowzoru, uczucie dumy wynikające z przynależności do legionów marszałka Józefa Piłsudskiego, zastąpionych w kontrafakturze wspólnotą internowanych, został wiernie zachowany przez anonimowego autora:

Nie peszą nas za oknem kraty,

Niestraszny nam niepewny los,

Nie pora rwać na piersiach szaty,

Lecz przeciwnościom śmiać się w nos!

\footnotetext{
12 Waryński w momencic aresztowania miał przy sobic 30 egzemplarzy świcżo wydrukowanej Warszau'ianki. „Picśni jednak nie aresztowano. Śpicwano ją w czasic robotniczych demonstracji na zesłaniu i katordzc. Stała siç bojowym hymnem rewolucji 1905 r. i 1917 r." (Z. Adrjański, Pieśni sercu bliskie, Warszawa 1976, s. 80).

${ }^{13}$ Zachował się także dopisek autora: „Tekst zrobiłem w celi nr 5, oddz. III - 16.02.82”. (Zob. Glosy zza muru. Wiersze i piosenki z ośrodków odosobnienia dla internowanych grudzien' '81-listopad '82, Polska, listopad 1982, s. 13).

14 Autorstwo melodii jest nadal kwestią sporną. Uważa się, że pierwowzorem melodii jest tzw. Marsz kielecki $n$ r 10 (marsz pułkowy syberyjskiego pułku piechoty rosyjskicj, stacjonującego w Kiclcach przed wojną), do oddziałów strzeleckich przeniesiony przez orkiestrę strażaków, która weszła w ich skład. Inna wersja mówi, że melodia pochodzi $z$ niemicckicj operetki Wir blaue Husaren. Zob. J. Ziomek, op. cit., s. 276; Byleś Polsko wolna była, op. cit., s. 119-120.
} 
My, internowani,

Lecz niepokonani,

Za kraj swój damy los,

Za wolne Związki - wolny głos!

Popularność melodii niejednokrotnie była jedynym źródłem inspiracji. Często wobec braku inwencji twórczej powielano gotowy schemat, nie nawiązując relacji intertekstualnych z oryginałem, rytmika wzoru wymuszała strukturę wersyfikacyjną, teksty wykorzystywały incipit, a także niektóre wersy w całości. W okolicznościowej poezji stanu wojennego nie jest to zjawisko rzadkie. Kontrafaktura powstała w ten sposób wykazuje powinowactwo neutralne.

Anonimowa pieśń legionistów z 1917 roku pod tytułem Wojenka lub Legun na wojence, rozpoznawana jednak dopiero przez incipit "Wojenko, wojenko, cóżeś ty za pani”, została wykorzystana do opisu sytuacji narodu po ogłoszeniu stanu wojennego. W tekście pojawiają się zapewnienia:

Wojenko, wojenko, nie wygrasz z narodem

oraz

Orła nie pokonasz, WRONo.

W kontrafakturze z roku 1982 starła się tradycja wojny sprawiedliwej, którą dotąd prowadzili Polacy (stąd pieszczotliwe określenie „wojenko”), z brutalną akcją generałów skierowaną we własny naród. Powinowactwo to możemy odczuwać więc jako polemiczne.

Wojenko, wojenko,

Cóżeś ty za pani,

Kiedy nie ma wroga,

Kiedy nie ma wroga,

Ty wojujesz z nami!

Chcą nas wziąć terrorem,

Bo nie mogli głodem,

Wojenko, wojenko,

Wojenko, wojenko,

Wojujesz z narodem.

Największa ilość kontrafaktur powstała jednak na bazie „zakazanych piosenek” i folkloru okupacyjnego. Stan wojenny w powszechnej świadomości jawil się jako wojna z narodem i porównywany był do okupacji hitlerowskiej. By podkreślić barbarzyństwo polityki zapoczątkowanej 13 grudnia 1981 roku i wskazać jednoznacznie, że ma ona charakter walki „obcych sił” z narodem, na murach pojawiały się swastyki, a podczas demonstracji skandowano: „Zomowcy-gestapowcy!” (lub „hitlerowcy”). Konotacje okupacji niemieckiej wywoływały zbrojne oddziały żołnierzy czy ZOMO, wyprowadzone na ulice polskich miast czołgi $\mathrm{i}$ wozy pancerne oraz 
wprowadzenie godziny milicyjnej. Zadanie doraźnego komentowania rzeczywistości przejął wiersz wojenny, który do najszerszych kręgów odbiorców docierał w konwencji piosenki.

Jak zauważył Jerzy Święch, opisujący analogiczne zjawisko w poezji konspiracyjnej lat 1939-1945:

nowa misja, jaką obarczono poezję, polegała na tym, iż miała stanowić integralny składnik walki ${ }^{15}$,

ponieważ, jak pisze Jan Dobraczyński:

Tam, gdzie wśród walki powstaje poezja, tam ujawnia się wola zwycięstwa. Poezja jest także bronią walczącego narodu, więc póki ona brzmi, póty naród nie upadł, ale walczy i ufa w zwycięstwo ${ }^{16}$.

Takie zadanie pełniła również okolicznościowa poezja stanu wojennego. Satyra i humor przejęty z piosenki konspiracyjnej ośmieszał wroga; najeźdźca, z którego można było drwić, przestawał być straszny; piosenki były źródłem siły, sugerowały, że można okupanta pokonać.

Okupacyjna piosenka Dnia pierwszego września roku pamiętnego posłużyła za wzorzec metryczny dla najliczniejszej grupy utworów spośród tekstów powstałych w stanie wojennym, dokumentujących wydarzenia 13 grudnia 1981 roku i sytuację, będącą konsekwencją tego dnia:
Trzynastego grudnia
roku pamiętnego
WRON napadł na Polskę
z kraju sąsiedniego.

Warianty tej pieśni tworzą historię stanu wojennego, w którą wpisane są dramaty osobiste, tragedia narodu po raz kolejny upominającego się o swoje prawa i kierującego słowa oskarżenia w stronę władzy i generała Jaruzelskiego. Lektura tych wierszy prowadzi do szczegółowego poznania zaistniałej sytuacji, utrudnień, nakazów wprowadzonych dekretem o stanie wojennym, elementów biografii ludzi znanych, często zajmujących później stanowiska państwowe. Pojemność semantyczna pieśni Dnia pierwszego września była tak duża, że do kontrafaktury przeniknęła także stylistyka dokumentacyjna.

Humor i ironia widoczne w tych wierszach pozwalały przetrwać trudny czas i były formą obrony. Stwierdzenie:

Jakiś człowiek płacze, stojąc po gazetę:

Jak ja po dziesiątej wyskoczę na setę?

- czyniło z dekretów stanu wojennego absurdalny akt, któremu nie wróżono długiej przyszłości. Melodia okupacyjnej piosenki posłużyła do wyrażenia uczuć dezaprobaty w stosunku

\footnotetext{
15 J. Święch, Pieśi niepodlegla. Model poezji konspiracyjnej, Warszawa 1982, s. 30.

16 J. Dobraczyński, Wstęp, w: Stowo prawdziwe, Warszawa 1942, s. 31.
} 
do postawy polskiego żołnierza, czynnie wspierającego politykę generałów, w wierszu Do żolnierza oraz potwierdzenia rozczarowania polskich robotników:

Trzynastego grudnia roku pamiętnego

robotnik zrozumial, że Polska nie jego.

Trzynastego grudnia roku pamiętnego

Wzięła nas milicja z domu rodzinnego,

Płacze żona, dzieci: „Co wy to robicie,

Gdzie wy mi, bandyci, męża prowadzicie?”

Nieskomplikowany zabieg włożenia własnego tekstu w gotową strukturę wersyfikacyjną, powielenie rytmiki, przejęcie rekwizytów i leksyki wojennej, zaowocowal powstaniem sporej liczby kontrafaktur innej okupacyjnej piosenki Siekiera, motyka. Powszechnie znana melodia służyła popularyzacji treści utworu.

Siekiera, motyka, katar sienny,

Mamy w Polsce stan wojenny,

Siekiera, motyka, gaz i prąd,

Kiedy oni pójdą stąd?

Siekiera, motyka, bimber, szklanka,

Na pochodzie jest łapanka,

ZOMO, pały, woda, gaz,

Lecz to nie przeraża nas.

Siekiera, motyka i car Lonia, macie wprawdzie już Kuronia,

macie także już Michnika,

lecz w narodzie duch nie znika.

W wariancie powstałym w Białołęce Wojciecha Jaruzelskiego stawia się na równi ze zbrodniarzami ludzkości: Hitlerem, Pinochetem i Pol-Potem:

Siekiera, motyka, piłka, metal,

Mamy swego Pinocheta.

Jak weźmie do ręki sierp i młot,

Będzie walczył jak Pol-Pot.

Poetom 13 grudnia za wzór posłużyła także piosenka okupacyjna Teraz jest wojna, znana również z filmu Zakazane piosenki. Nawiązujący do niej utwór Zielona wrona jest literackim zapisem dokumentującym wprowadzenie stanu wojennego:

Ekstrema już śpi, szczekają gdzieś psy,

Skończyla się wolna sobota, 
Wyruszył sznur suk, grzmią buty o bruk,

Ktoś do drzwi gwałtownie łomota.

Zielona wrona,

Dziób w wężyk szamerowany,

Kto nie dał drapaka,

Kto nie chce zakrakać,

Ten będzie internowany.

Grudniowy wstał świt, nie wiedział nic nikt,

Milczały jak grób telefony,

Aż w radio wódz sam obwieścił, że stan

Wojenny jest wprowadzony.

Zielona wrona...

Od tego poranka codzienna łapanka

Szalała w bezsilnej wściekłości.

Od tego poranka zrobili internat

Dla członków Solidarności.

Zielona wrona...

Kolejną grupę kontrafaktur tworzą utwory powstałe $z$ inspiracji popularnych piosenek i melodii ludowych. Wykorzystano między innymi melodię piosenki lwowskich batiarów: Bal u ueteranów, Marsz, marsz, Polonia, Jak dtugo na Wawelu, Ptynie Wista, ptynie i inne.

Ludowa piosenka Umart Maciek, umart posłużła za wzór satyrycznemu utworowi Umart Sustow, umart. Kpiarski, ironiczny ton tej piosenki, śpiewanej w Kupkowie, służy opisaniu wzajemnych związków przywódców Polski i Związku Radzieckiego, zdaniem autora opartych na służalczości i strachu strony polskiej. Przedmiotem wyszydzenia są: Wojciech Jaruzelski, Leonid Breżniew — pierwszy sekretarz Komunistycznej Partii Związku Radzieckiego i Michaił Susłow, ideolog KPZR, wrogo usposobiony do „Solidarności”.

Umarł Susłow, umarł,

Już leży na desce,

Gdyby Lońka ryknął,

Podskoczyłby jeszcze.

Bo w czerwonym taka dusza,

Lońka ryknie, to się rusza.

Oj dana, dana...

Ryknął se raz mocno

Bardzo na Wojciecha:

„Skażi, kagda wreszcie 
Weźmiesz się za Lecha?”-

Wojtek mało nie potracił

Swoich generalskich gaci.

Oj dana, dana...

I Wojtek w te pędy

Uformował WRONę,

Pozbierał ubeków

I najmitów ZOMO.

"Chłopcy, zbierzcie się w kupę

I ratujcie moją dupę!”.

Oj dana, dana...

Spośród innych motywówludowych warto odnotowaćaktualizację pieśni Łowiczanka jestem w utworze Ekstremistka jestem oraz $A$ chachary żyja w przyśpiewce Nasza wtadza. Gra słowna, którą tu obserwujemy, polega na zestawieniu tekstu utworu pierwotnego $\mathrm{z}$ nową treścią i przetworzeniu incipitu:

Jedna wrona drugiej wronie

Wiesza dekret na ogonie.

Wśród muzycznych zapożyczeń znalazły się także popularne przeboje. Kontrafaktury powstawały do piosenek Maryli Rodowicz: Dzis prawdziwych Cyganów już nie ma („Dziś prawdziwej ekstremy już nie ma” z refrenem: „Tylko KOR-u, tylko KOR-u, tylko KOR-u żal”) i Jadq wozy kolorowe („Jadą wozy ciężarowe z gliniarzami”) oraz grupy „Pod Budą”. Bardzo smutna piosenka retro (z charakterystyczną melodią refrenu „Kap, kap, płyną łzy...”) posłużyła poecie do sportretowania posła Janusza Przymanowskiego, któremu wypomina się służalcze, aprobujące stan wojenny, wystąpienie w sejmie:

$$
\begin{aligned}
& \text { Przy-, Przy-manow-ski, } \\
& \text { Czyś ty aby jest pol-ski? } \\
& \text { Pośle Przymanowski, } \\
& \text { Chyba tyś ru-ski! }
\end{aligned}
$$

W Głogowie więzienny zespół „Kabaryna” w kwietniu 1982 roku do swego repertuaru włączył Polską sambę, śpiewaną na melodię Samba sikoreczka przez znany w środowisku studenckim zespół „Nasza Basia kochana”. Muzyka Jerzego Filara stała się interpretantem, wykorzystanym do wykazania obłudy władzy, która internowanym proponowała opuszczenie kraju. Anonimowy poeta wzywał do wierności dotychczasowym przekonaniom:

Po gorącym lecie,

Przyszła chłodna zima,

Była demokracja,

A teraz jej ni ma.

Za kratami siedzisz, 
Przemoc cię nie zgina,

Naród na nas czeka,

Więc i ty się trzymaj!

Patrz wszystkim w oczy szczerze,

Wierz w siebie, jak ja wierzę.

Z kraju nie ucieka się,

Kiedy w kraju tym jest źle,

Samba - (wojenna) - nasza samba.

Na zakończenie rozważań o kontrafakturach powstałych w okresie stanu wojennego warto wspomnieć o twórcach, których utwory w sposób szczególny i czasami niezamierzony przez autorów związały się z tamtym mrocznym czasem. Słuchacze utworów Jacka Kaczmarskiego, Jana Krzysztofa Kelusa, Leszka Wójtowicza, Jana Pietrzaka odbierali ich songi jako jedną wielką, ciągle aktualną pieśń protestu. Obecny w ich tekstach motyw kajdan, murów, krat, ale i świtu, świadczy, że „pokolenie Sierpnia '80" miało swoich bardów. Wszyscy internowani, a także ci nieosadzeni, którym wprowadzenie stanu wojennego odebrało należny osobie ludzkiej przywilej wolności, utożsamiali się z bohaterem Murów Jacka Kaczmarskiego (piosenka powstała jeszcze w 1976 roku jako parafraza utworu Luisa Llacha Mur):

On natchniony i młody był, ich nie policzyłby nikt.

On im dodawał pieśnią sił, śpiewał, że blisko już świt.

Świec tysiące palili mu, znad głów podnosił się dym,

Śpiewał, że czas, by runął mur...

Oni śpiewali wraz z nim:

Wyrwij murom zęby krat,

Zerwij kajdany, połam bat!

A mury runą, runą, runą

I pogrzebią stary świat! (..)

Swoją historię ma też hymn Solidarnośc ${ }^{17}$. W okresie stanu wojennego słowa „Solidarni, nasz jest ten dzień" śpiewali wszyscy internowani. Pieśnią bardzo popularną była też Ostatnia szychta na KWK „Piast” (muzyka: Jan Krzysztof Kelus).

Tworzenie i rozpowszechnianie takich utworów władze stanu wojennego karały więzieniem, upatrując w nich jedno ze źródeł siły upodlonych i poniżonych obywateli. Szczególnym świadectwem są słowa Jana Kelusa, napisane w Białołęce w lipcu 1982 roku:

Przebywam obecnie w celi 11, oddz. 4, paw. 4 więzienia w Białołęce. Znalazłem się tutaj w związku z podejrzeniem, iż mam coś wspólnego z autorstwem lub wykonawstwem (tzw. „organa ścigania” nie uważały za stosowne tego sprecyzować)

17 Sł. Jerzy Narbutt, muz. Stanisław Markowski, prawykonanic Filharmonia Krakowska, 31 stycznia 1981 roku (podczas uroczystości $O$ wolność $i$ niepodleglość, poświęconej 118. rocznicy wybuchu powstania styczniowego), wyk. chór „Organum” (dyr. Bogusław Grzybck) 
piosenki, która nadana została w pierwszej audycji podziemnego radia „Solidarność”. Ponieważ żaden artysta nie ma obowiązku porozumiewać się z calym światem - a moja np. twórczość nie była i nie jest w zasadzie adresowana do tzw. organów - uznałem za słuszne nie wdawać się z nimi w jakąkolwiek rozmowę. Organa zaś ze swej strony zadecydowały, że nie leży w ich interesie wdawać się w poszlakowy proces o zakazaną piosenkę. Tym bardziej, że zamiast mozolnie zamieniać marne poszlaki w niezbite dowody (...) - można mnie było po prostu internować. Przebywam więc obecnie w więzieniu. I będąc w nim - staram się robić swoje. To znaczy między innymi robić piosenki ${ }^{18}$.

Kontrafaktury i piosenki Leszka Wójtowicza: Moja litania, Jana Pietrzaka Żeby Polska byta Polska oraz utwory Jacka Kaczmarskiego, Przemysława Gintrowskiego i Jana Krzysztofa Kelusa tworzą dopiero całościowy obraz liryki okolicznościowej stanu wojennego.

18 J. K. Kclus, Z nieskoniczonq uriqż piosenką 1980-1982, Warszawa 1982, s. 47. 